\title{
Principal leadership style, school performance, and principal effectiveness in Dubai schools
}

\author{
Ibrahim, Ali S.
}

Faculty of Education, United Arab Emirates University, UAE (ibrahim6@gmail.com)

Al-Taneiji, Shaikah

Faculty of Education, United Arab Emirates University, UAE (shaikaha@uaeu.ac.ae)

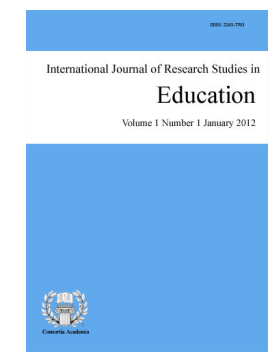

ISSN: 2243-7703 Online ISSN: 2243-7711

Received: 28 February 2012

Revised: 16 May 2012 DOI: $10.5861 /$ ijrse.2012.86

OPEN ACCESS

\section{Abstract}

This study investigated whether a correlation exists between the principal's leadership style and both a) performance level and b) the principal's effectiveness in schools in Dubai. It also investigated whether the correlations change according to the principal's gender, years of experience, and the level of the school (primary, intermediate, and secondary). Data on principals' leadership styles and effectiveness were collected through Avolio and Bass' (1995) Multifactor Leadership Questionnaire (MLQ) completed by teachers in 34 government schools. Data on school performance were obtained from the 2010 Dubai Schools Inspection Bureau report. The study found that the transformational leadership style was most frequently employed, followed by the transactional style, and then the passive or avoidant style. The study found a positive correlation between the principal leadership style and his/her effectiveness, but found no correlation with school performance. Finally, principal style and effectiveness differed according to the principal's gender and the level of the school, but not according to the principal's years of experience. Findings of this study open a new area of research on school principalship, performance, and effectiveness in the UAE.

Keywords: Principals; leadership styles; school performance; Dubai; UAE education 


\section{Principal leadership style, school performance, and principal effectiveness in Dubai schools}

\section{Introduction}

The variables associated with improved student achievement and more generally with improved school performance have been a focus of research for many years. The general assumption is that the presence or absence of effective school leaders, positive school climates, and positive attitudes of teachers can, directly or indirectly, influence school performance and student achievement (Hallinger \& Heck, 1998; Kruger, Witziers, \& Sleegers, 2007; Waters, Marzano, \& McNulty, 2004; Witziers, Bosker, \& Kruger, 2003). While the equation of effective school leadership and improved school performance appears to be relatively simple and straightforward in theory, in practice it is complex and unpredictable. Cotton (2003) argues that while it is evident that a fundamental connection between the principal's leadership style and school performance in terms of student achievement exists, research on this relationship begins and ends with that concept.

Harris (2004) and Storey (2004) add that although the leadership field is replete with often largely descriptive studies of effective leadership, these studies have rarely tracked or explored, with sufficient rigor, the relationship between leadership and school performance. Harris (2004) states that

We do not know, for example, exactly what forms of leadership result in [high performing] schools, across different school contexts, and in different types of schools. We do not know what particular combination of experience, training, and professional development most benefits leaders wishing to improve their schools. Of most concern is the fact that we have very few studies that have explored the relationship between leadership and student learning outcomes in any depth. The correlational nature of the research evidence that does exist inevitably masks the exact patterning and nature of the relationship between leadership and enhanced student learning (p. 4).

\subsection{School Leadership Styles}

Researchers have discerned a number of school leadership patterns or styles, the most commonly known having been identified by renowned social scientist Kurt Lewin and his colleagues in 1939. These are authoritarian or autocratic, democratic or participative, and laissez-faire or passive: the authoritarian leader makes all decisions, independent of members' input; the democratic leader welcomes team input and facilitates group discussion and decision-making; and the laissez-faire leader allows the group complete freedom for decision-making without participating himself/herself.

In 1967, Likert suggested another set of styles: exploitive authoritative, benevolent authoritative, consultative, and participative. In exploitive authoritative style, the leader has low concern for people and uses such methods as threats and punishments to achieve conformance. When an authoritative leader becomes concerned for people, a benevolent authoritative leader emerges. The leader now uses rewards to encourage appropriate performance and listens more to concerns, although what he/she hears is often limited to what subordinates think that the leader wants to hear. In consultative style, the leader is making genuine efforts to listen carefully to ideas; nevertheless, major decisions are still largely centrally made. At the participative level, the leader engages people in decision-making; people across the organization are psychologically closer and work well together at all levels.

Another set of school leadership styles was coined by Burns (1978): transactional leadership and 
Principal leadership style, school performance, and principal effectiveness in Dubai schools

transformational leadership. These two styles have dominated scholarly debate as the major conceptual models of school leadership since the early 1980s (Hallinger, 2003; Marks \& Printy, 2003). Along with passive/avoidant leadership, transactional and transformational leadership form a new paradigm for understanding both the lower and higher order efforts of leadership styles. This paradigm builds on earlier sets of autocratic versus democratic or directive versus participative leadership (Avolio \& Bass, 2004).

Transformational leadership can be defined as increasing the interest of the staff to achieve higher performance through developing the commitments and beliefs in the organization (Bass, 1985). It entails moving people to a common vision by building trust and empowerment (Carlson, 1996). Transformational leaders are motivating, influential, and proactive. They optimize people's development and innovation and convince them to strive for higher levels of achievement (Avolio \& Bass, 2004). According to Burns (1978), transformational leaders form a relationship of mutual stimulation and elevation that converts followers into leaders. As articulated by Bass (1985), four factors characterize the behavior of transformational leaders: individual consideration, intellectual stimulation, inspirational motivation, and idealized influence. Individual consideration denotes giving personal attention to members who seem neglected. Intellectual stimulation focuses on enabling members to think of old problems in new ways. Inspirational motivation is typified by communicating high performance expectations. Finally, idealized influence emphasizes modeling behavior through exemplary personal achievement, character, and conduct.

Transactional leadership, on the other hand, is based on the reciprocal exchange of duty and reward that are controlled by the principal. Transactional leadership is defined by Avolio and Bass (2004) as setting up and defining agreements or contracts to achieve specific work objectives, discovering individuals' capabilities, and specifying the compensation and rewards that can be expected upon successful completion of the tasks. Transactional leaders focus on the basic needs of their staff (Bass, 1985), but they are not interested in providing high level motivation, job satisfaction, or commitment. Bass and Avolio (1994) describe three forms of transactional leadership: passive management-by-exception, active management-by-exception, and constructive transactional. Passive management-by-exception involves setting standards but waiting for major problems to occur before exerting leadership behavior. Leaders who demonstrate active management-by-exception pay attention to issues that arise, set standards, and carefully monitor behavior. They believe that they should not take risks or demonstrate initiative. A constructive transactional leader sets goals, clarifies desired outcomes, exchanges rewards and recognition for accomplishments, suggests and consults, provides feedback, and gives employees praise when it is deserved.

According to Bass (1985), transformational leaders are more likely to be proactive than reactive in their thinking, and more creative, novel, and innovative in their ideas. Transactional leaders may be equally intelligent but their focus is on how to keep the system for which they are responsible running-reacting to problems generated by observed deviances, and looking to modify conditions as needed. Bass (1998) believes that every leader displays practices of both styles to some extent. Although transformational and transactional leadership are at opposite ends of the leadership continuum, he maintains that the two can be complementary (see also Leithwood \& Jantzi, 2000). The ideal leader would practice the transformational components more frequently and the transactional components less frequently. Bass and Avolio (1994) embrace this "two-factor theory" of leadership and believe that the two build on one another. The transactional components deal with the basic needs of the organization, whereas the transformational practices encourage commitment and foster change.

It should be noted that by 1990 researchers were advocating transformational leadership and other forms of leadership that were more consistent with evolving trends in educational reform, such as empowerment, shared leadership, and organizational learning (Hallinger, 2003; see also Avolio, 1999; Bass 1997, 1998; Bass \& Avolio, 1994; Leithwood, Begley, \& Cousins, 1994; Leithwood \& Jantzi, 2000; Silins \& Mulford, 2002). While this shift from more managerial, or transactional, leadership to dispersed, or transformational, leadership was evident in literature, it remains questionable as to whether these changes are evident in the practices of administrators. Considering the realities of schools today, many school principals are doing their best to make it through any 
given day just managing the diverse needs of the school community; the time necessary for a transformational leader to build trust, commitment, interdependence, and empowerment of teachers and staff is not always available. In some contexts, not every leader has the ability to convince their subordinates to make an effort to perform at a high level. Transactional leaders, in contrast, do not dedicate much time to developing their subordinates; instead, they wait until they either fail or succeed and then react.

\subsection{Leadership Styles and School Performance}

As stated above, while the correlation between school leadership and school performance appears to be relatively simple and straightforward in theory, in practice it is inherently complex and unpredictable. Research on this correlation gives mixed results. On the one hand, there are studies which confirm the existence of a relationship between school leadership style and school performance. For example, Ubben and Hughes (1992) found that principals could create a school climate that improves the productivity of both teachers and students and that the leadership style of the principal can foster or restrict school effectiveness.

Hallinger and Heck (1998) reviewed over 40 empirical studies conducted between 1980 and 1995 and concluded that principals exercised a measurable and statistically significant, though small, indirect impact on school effectiveness and student achievement. Similarly, Witziers, Bosker, and Kruger (2003) found that school leadership does have a positive and noteworthy effect on student achievement and Waters, Marzano, and McNulty (2004) reported that effective school leadership substantially increases student achievement. Using a path analysis, Kruger, Witziers, and Sleegers (2007) found that school leaders indirectly influence student outcomes and school culture. In the context of Cyprus, Kythreotis and Pashiardis (2006) found direct effects of the principal's leadership style on student achievement and Kythreotis, Pashiardis, and Kyriakides (2010) reached the conclusion that "the principal human leadership frame affects student achievement" (p. 232). The strong interpersonal relations in the Cyprus education system were a main reason for the significance of the human leadership frame. Moreover, the small size of primary schools in Cyprus and the nature of primary schools compared to secondary schools permit the development of strong interpersonal relations.

Research into leadership styles has found that women are slightly stronger in relationship-oriented supportive styles, while men score higher in instructive and controlling styles (Fennell, 2005; Kruger 1996, 2008). Eagly, Johannesen-Schmidt, and Van Engen (2003), for example, offered a quantitative synthesis of 45 studies on transformational, transactional, and laissez-faire leadership styles, comparing women and men. They found that women scored higher than men in transformational leadership and contingent reward, whereas men scored higher than women in active and passive management-by-exception and on laissez-faire leadership. Moreover, women produced considerably better outcomes than men on all of the three outcome measures that the Multifactor Leadership Questionnaire investigated: the extra effort they inspired from subordinates, the satisfaction that people expressed about their leadership, and their overall effectiveness in leading. Kythreotis and Pashiardis (2006) also found that female school principals' impact student achievement more than male school principals. They argue that interpersonal relations constitute a more central point of reference of the managerial style of women and allow them to exhibit a more democratic and participative style (see also Coleman, 1998).

On the other hand, some studies found no relationship between school leadership styles and effectiveness of schools. The purpose of Di Vincenzo's (2008) research, for example, was to determine whether the practice of transactional and transformational leadership behaviors consistently contribute to higher levels of student achievement as reflected in the results of standardized tests. He found no statistically significant correlational relationship between the leaders' attributes as determined by Kouzes and Posner's Leadership Practices Inventory (Kouzes, 2003) survey instrument and resultant student achievement as determined by standardized test results. Using Bass and Avolio's (1994) Multifactor Leadership Questionnaire, Huffman (2003) found no relationship between leadership styles (transformational, transactional and laissez-faire) and improved student achievement. It was concluded, however, that transformational leadership was related to increased teacher 
Principal leadership style, school performance, and principal effectiveness in Dubai schools

satisfaction, greater perception of principal effectiveness, and increased willingness on the part of teachers to give extra effort. This conclusion was in line with Avolio's (1999) finding that transformational leadership generally generates greater follower effectiveness and satisfaction than transactional leadership, although effective leaders certainly perform using the two styles.

The fact remains that transformational leadership focuses more on the relationship between leaders and followers than on the educational work of school leadership. The quality of these relationships, as stated above, is not unequivocally predictive of the quality of student outcomes. Instructional leadership goes beyond building collegial teams, a loyal and cohesive staff, and sharing an inspirational vision to focus such relationships on some very specific pedagogical work. In this context, Marks and Printy (2003) conducted a qualitative-quantitative study of 24 schools in the United States and found that transformational leadership is a necessary but insufficient condition for instructional leadership (with the focus of the principal on curricular and instructional issues that directly affect student achievement (Cotton, 2003)). When transformational leadership and instructional leadership coexist in an integrated form of leadership, the influence on school performance, measured by the quality of its pedagogy and the achievement of its students, is substantial. Dumay (2003) also found that the comparison between instructional and transformational leadership showed that the impact of the former is three to four times that of the latter in terms of student achievement.

The problem with instructional leadership, however, is that in many schools the principal is not the educational expert; principals often have less expertise than the teachers they supervise. Moreover, some principals perceive their role to be administrative - as in the UAE - and, as such, they purposely distance themselves from the classroom environment and leave pedagogical issues to teachers, master teachers, and supervisors. This notion is further complicated by the fact that the principal's authority is severely limited as he/she occupies a middle management position. In many school systems, including in the UAE, the ultimate authority exists with the senior administrators in the district or divisional office. Many school principals are so engrossed in the managerial and administrative tasks of daily school life that they rarely have time to lead others in the areas of teaching and learning.

\subsection{Dubai Schools Inspection}

One aim of this study was to investigate whether a relationship existed between school performance and the principal's leadership style in Dubai schools. Data on school performance were obtained from the findings of school assessment conducted by Dubai Schools Inspection Bureau (DSIB). The idea of monitoring and assessing performance in Dubai schools began with the Dubai Education Council in 2005. One year later, the Knowledge and Human Development Authority (KHDA) was created. Following this, Dubai Schools Inspection Bureau was formed in 2007. Then, a framework for inspecting schools was developed during a series of pilot inspections in April 2008. In October 2008, the DSIB inspected 189 schools out of 220 schools in Dubai (excluding Indian, Pakistani, and Iranian schools, which were added to inspections from 2009 and onward). Teams of two to seven inspectors visited all 189 schools for two to five days, depending on the number of students in the school. As a result of the visits, schools were classified over four categories: unsatisfactory, acceptable, good, and outstanding (DSIB, 2009).

In 2009, the DSIB inspected schools for the second time (including 23 private schools offering Indian and Pakistani curricula) and conducted a series of follow-through inspections of the 22 schools rated unsatisfactory in the previous year. In the second year of inspection, the DSIB used a similar, although not identical, framework for inspection and assessed six areas: engaging and motivating students, teaching for effective learning, assessing students' achievement in key subjects, supporting and caring for students, leading schools to improve students' learning, and working together to improve schools (DSIB, 2010, pp. 10-11).

Not surprisingly, the re-inspection of schools within a period of a single year produced, in many respects, similar outcomes to those generated in the first round of inspections (DSIB, 2010). In the third annual inspection, 
Ibrahim, A. S. \& Al-Teneiji, S.

the framework was developed to include seven areas: student attainment and progress, student personal and social development, teaching and learning, curriculum, protecting and supporting students, leadership and management, and the school's overall performance (DSIB, 2011). This study used the DSIB assessment of schools of the 2010 Annual Report, since it is the only detailed report that classified schools based on a four-point scale of unsatisfactory, acceptable, good, and outstanding.

\subsection{Problem of the Study}

The above contradiction in research findings indicates a necessity for more studies that examine the possible relationships between school leadership style, school performance, and school effectiveness. In addition, there is scarcity of research on this issue in the Arab world, which is evident in the literature review that draws upon the significant works in Western literature, but has found no work on the Gulf Arab principal's leadership styles. In the United Arab Emirates, the belief is that the school principal's leadership style is connected to school performance (as evidenced by higher academic achievement of students) and more generally to school effectiveness. However, no previous study investigated this assumption; therefore, this study attempted to fill this research gap.

\subsection{Research Questions}

The study answered the following questions:

1. What are the leadership styles of principals in Dubai schools?

2. What is the relationship between the principal's leadership style and school performance?

3. What is the relationship between the principal's leadership style and effectiveness?

4. Does the principal's leadership style differ according to the principal's gender, school level, and years of experience?

5. Does the principal's effectiveness differ according to the principal's gender, school level, and years of experience?

\section{Research Methodology}

This study is quantitative correlational in nature. In order to identify principals' leadership styles in Dubai schools, the Multifactor Leadership Questionnaire (MLQ) by Avolio and Bass (1995) was used. The 2010 Dubai Schools Inspection Bureau report was utilized to identify the ranking of schools. Then, statistical analysis was used to find whether a correlation existed between the principal's leadership style and a) his or her effectiveness, and b) the performance level of the school. Finally, statistical analysis was used to find whether the principal's leadership style and his/her effectiveness differed according to the principal's gender, years of experience, and school level (primary, intermediate, and secondary).

\subsection{Instrument}

The instrument used in this study was divided into two sections. The first included the demographic information of the sample, such as school level, principal's gender, and principal's years of experience. The second section is the most recent version (Form 5X) of the Multifactor Leadership Questionnaire (MLQ) by Avolio and Bass (1995), translated into Arabic by the authors. The MLQ has been used extensively in field and laboratory research to study transformational, transactional, and passive/avoidant leadership styles. The questionnaire contains 45 items of which the first 36 measure different kinds of leadership style and the last 9 items measure the principal's effectiveness. The researchers changed the Arabic words ma3had and koliyah (institute and college) in statements 34 and 43 to the word madrasah (school) so as to fit the context of the 
Principal leadership style, school performance, and principal effectiveness in Dubai schools

current study. MLQ includes twenty statements that investigate four components of transformational leadership: charismatic leadership or idealized influence, inspirational motivation, intellectual stimulation, and individualized consideration. It also includes eight statements that investigate two components of transactional leadership: contingent reward and active management-by-exception Finally, it contains eight items to assess passive management-by-exception and laissez-faire or passive/avoidant leadership behaviors. The MLQ items were assessed over a scale from 0 (never observed) to 4 (frequently observed). The internal reliability of the MLQ for this current study was assessed using Cronbach's Alpha. The result was 0.95, which indicates that the questionnaire was highly reliable.

\subsection{Procedures and Sample}

The Dubai Education Zone (DEZ) helped in selecting schools, and distributing, and collecting questionnaires. A stratified representative sample was aimed for based on the school performance level in the following manner: in each of the four levels of performance (unsatisfactory, acceptable, good, and outstanding), as identified by the DSIB 2010 report, DEZ was asked to obtain completed questionnaires from ten (five male and five female) public schools at each level. In each school, twenty teachers should have responded to the MLQ referring to their principal's leadership style and effectiveness. Thus, the sample would be 800 teachers. The returned completed surveys comprised 490 from 34 schools with a response rate of $61.25 \%$. The sample consisted of $219(44.7 \%)$ male teachers and 271 (55.3\%) female teachers. The demographic information is summarized in Table 1.

Table 1

Demographic Information of Schools

\begin{tabular}{llc}
\hline & Number of schools & Percentage \\
\hline $\begin{array}{l}\text { Gender } \\
\text { Male }\end{array}$ & 14 & \\
Female & 20 & $41.2 \%$ \\
School Level & & $58.8 \%$ \\
Kindergarten & 2 & \\
First Cycle (grades 1-5) & 10 & $5.9 \%$ \\
Second Cycle (grades 6-9) & 11 & $29.4 \%$ \\
Third Cycle (grades 10-12) & 8 & $32.3 \%$ \\
Second \& Third & 3 & $23.5 \%$ \\
Principal's Years of Experience & & $8.9 \%$ \\
0-4 years & 7 & \\
5-9 years & 5 & $21.8 \%$ \\
10-15 years & 14 & $15.6 \%$ \\
More than 15 & 6 & $43.8 \%$ \\
\end{tabular}

Based on the DSIB report, sixteen schools participating in this study have been evaluated as acceptable, which is the highest percentage (47\%). The second category was good with twelve schools (35\%), followed by five schools $(15 \%)$ as unacceptable, and the least common category, which was excellent, included only one school (3\%) from the sample.

\section{Results}

\subsection{Question One}

What are the leadership styles of principals in Dubai schools?

The first 36 questions of the MLQ were used to identify the leadership style of each principal of the participating schools. These items were divided into three major scales: transformational (20 items), 
Ibrahim, A. S. \& Al-Teneiji, S.

transactional (8 items), and passive leadership ( 8 items) (Avolio \& Bass, 1995). Two techniques were used to conduct the analysis for this question. First, average means by scales were calculated by adding scores for all responses of a scale's items and dividing them by the total number of responses for that item. Blank answers were not included in the calculation. Results of this analysis are presented in Table 2.

Table 2

Leadership Styles by Means

\begin{tabular}{llcc}
\hline \multicolumn{1}{c}{ Leadership style } & & Means of sub-styles & Average Means \\
\hline Passive or Avoidant & Laissez-faire & 0.93 & 1.088 \\
& Passive management-by-exception & 1.25 & \\
Transactional & Contingent reward & 3.34 & 3.215 \\
& Active management-by-exception & 3.09 & \\
Transformational & Individualized influence (attributes) & 3.49 & 3.303 \\
& Individualized influence (behaviors) & 3.18 & \\
& Inspirational motivation & 3.53 & \\
& Intellectual stimulation & 3.21 & \\
& Individualized consideration & 3.10 & \\
\hline
\end{tabular}

Second, after reversing the negative items (those of passive and avoidant leadership), the total score of the questionnaire ranged from 0 to 144 with an average of 72 . This range was divided into the following four categories: $0-36,37-72,73-108$, and 109-144, which represent four sections that can be observed over a continuum from ideal passive leadership to ideal transformational leadership. The wider the range of school teachers' responses, the more positive the attitudes and behaviors of the school principal, and the more he/she leans toward the transformational leadership style. The results of this analysis are summarized in Table 3.

Table 3

School Principals' Styles as Measured by the $M L Q$

\begin{tabular}{ccc}
\hline Section & N & Percentage \\
\hline $0-36$ & 2 & 0.4 \\
$37-72$ & 26 & 5.3 \\
$73-108$ & 117 & 24 \\
$109-144$ & 342 & 70.2 \\
\hline
\end{tabular}

As can be observed in Tables 2 and 3, the transformational leadership style was the most practiced style by school principals. The second in rank is the transactional style of leadership, and last is the passive or avoidant style.

\subsection{Question Two}

What is the relationship between the principal's leadership style and school performance?

As mentioned above, the DSIB report allocated each school one of four ranked categories: unsatisfactory, satisfactory, good, and outstanding. Also, the MLQ categorized principals of these schools into one of four sections over the leadership continuum. To calculate the correlation between the two variables, a non-parametric correlation procedure was used because both variables were measured at ordinal level. The Spearman's rho correlation value between the two variables was .11 and it was significant at .05 level. However, there is a very limited tendency for one variable to increase or decrease when the other increases or decreases. Therefore, although this correlation value was statistically significant, practically it cannot be taken into account. 
Principal leadership style, school performance, and principal effectiveness in Dubai schools

\subsection{Question Three}

What is the relationship between the principal's leadership style and effectiveness?

Principals' effectiveness was measured by the last nine items of the MLQ. The relationship was estimated by calculating the correlation coefficient between the total score of each school on the MLQ (36 items) and the total score of each school on the principals' effectiveness scale ( 9 items). The Pearson correlation value was .88 and it was statistically significant at .05 . This high correlation indicates that there is a strong and positive relationship between leadership style and principals' effectiveness. In other words, the more school principals' attitudes and behaviors move toward the fourth section of the leadership continuum (transformational leadership), the more teachers will perceive that their principals are effective.

\subsection{Question Four}

Does the principal's leadership style differ according to the principal's gender, school level, and years of experience?

To answer this question, an independent t-test was conducted to compare the two genders, and two ANOVA tests were conducted to compare the school levels and the principal's years of experience separately. The t-test results are presented in Table 4.

Table 4

Comparing Leadership Styles by Gender

\begin{tabular}{cll}
\hline Gender & Mean & SD \\
\hline Male & 110.38 & 20.09 \\
Female & 117.86 & 22.59 \\
\hline
\end{tabular}

The mean and standard deviation of leadership styles of female principals were higher than those of male principals. The mean difference between the two genders was statistically significant as assessed by the independent $\mathrm{t}$-test $(\mathrm{t}=-3.83, P<.01)$. The results of ANOVA tests to compare over school levels and the principal's years of experience are summarized in Table 5.

\section{Table 5}

Comparing Leadership Styles by School Levels and Principal's Years of Experience

\begin{tabular}{lccccc}
\hline \multicolumn{1}{c}{ School level } & Mean & SD & $\begin{array}{c}\text { Principal's years of } \\
\text { experience }\end{array}$ & Mean & SD \\
\hline Kindergarten & 129.71 & 11.09 & $0-4$ years & 115.76 & 18.26 \\
First & 119.79 & 17.21 & $5-9$ years & 109.57 & 25.17 \\
Second & 112.86 & 22.28 & $10-14$ years & 117.83 & 17.06 \\
Third & 115.00 & 17.64 & More than 14 & 111.42 & 24.16 \\
Second \& Third & 89.47 & 31.20 & & & \\
\hline
\end{tabular}

The values of the means of the five school levels indicate that there are differences in the leadership styles. This observation was supported by the ANOVA result, which was statistically significant $\left(\mathrm{F}_{(4,485)}=20.87, P\right.$ $<.01)$. As for the principal's years of experience, there were also differences in leadership styles among the four levels of experience, as could be seen from the above table, however, these differences were not statistically significant $\left(\mathrm{F}_{(3,439)}=2.67, P=.05\right)$.

\subsection{Question Five}

Does the principal's effectiveness differ according to the principal's gender, school level, and years of 
Ibrahim, A. S. \& Al-Teneiji, S.

experience?

To answer this question, an independent t-test and two ANOVA tests were conducted.

Table 6

Comparing School Effectiveness by Gender

\begin{tabular}{ccc}
\hline Gender & Mean & SD \\
\hline Male & 29.84 & 6.44 \\
Female & 31.73 & 6.41 \\
\hline
\end{tabular}

As can be observed from Table 6, the mean value of the effectiveness of female principals was slightly higher than that of male principals. The mean difference between the two genders was statistically significant as assessed by the independent $\mathrm{t}$-test $(\mathrm{t}=-3.23, \mathrm{P}<.01)$. To compare by school level and the principal's years of experience, two ANOVA tests were conducted separately and the results were summarized in Table 7.

Table 7

Comparing Principal Effectiveness by School Level and Principal's Years of Experience

\begin{tabular}{lllccc}
\hline \multicolumn{1}{c}{ School level } & Mean & SD & Teaching Experience & Mean & SD \\
\hline Kindergarten & 34.30 & 2.72 & $0-4$ years & 31.17 & 5.45 \\
First Cycle & 32.39 & 5.25 & 5-9 years & 30.08 & 6.58 \\
Second Cycle & 30.07 & 7.12 & $10-14$ years & 31.86 & 5.52 \\
Third Cycle & 31.44 & 4.76 & More than 14 & 30.13 & 7.58 \\
Second \& Third & 24.35 & 9.22 & & & \\
\hline
\end{tabular}

The means of principals' effectiveness over the five school levels are different. These differences were found to be statistically significant $(\mathrm{F}(4,485)=16.10, \mathrm{P}<.01))$. As for the principal's years of experience, there were also differences in leadership styles among the four levels of experience as could be seen from the above table, however, these differences were not statistically significant $(\mathrm{F}(3,439)=1.62, \mathrm{P}=.184)$.

\section{Discussion}

Avolio and Bass (1995) argue that the MLQ is not designed to encourage the labeling of leaders. Rather, it is more appropriate to identify a leader or group of leaders with such terms as "more transformational" or "less transactional" (p. 113). The results of this study found that principals in 34 government schools in Dubai are more transformational than transactional or avoidant in their leadership attitudes and behaviors. This result is in alignment with what Al-Taneiji (2006) found in her study on Model Schools in the city of Al Ain, UAE. The result is indicative of the current reforms undertaken by the Ministry of Education's DSIB. Since the DSIB started conducting its annual assessment in 2008, school principals have made efforts to transform their schools to meet the performance standards set by the Bureau. In addition, Dubai has witnessed an enormous influx of teachers and consultants from the West who bring considerable expertise and who may have helped in adopting transformational approaches of leadership.

The study also found that the principal's leadership style is correlated with how teachers perceive him/her to be an effective leader. This is expected since the more a principal employs the transformational forms of leadership (idealized influence, inspirational motivation, intellectual stimulation, and individualized consideration), the more he or she is seen to be effective by teachers. In fact, the last nine items of the MLQ (those that assess principal effectiveness) bear similarity with the four forms of transformational leadership.

Furthermore, the study found that principal leadership style is not correlated with school performance according to the DSIB standards. It should be noted that the inspectors focused on six areas; one of them is student attainment and progress. DSIB school performance standards, thus, covered a much larger spectrum of 
Principal leadership style, school performance, and principal effectiveness in Dubai schools

activities than just how the school performed in terms of student attainment. This fact might have affected the results. However, the result is in concurrence with previous research (Di Vincenzo, 2008; Huffman, 2003; Kouzes, 2003), which found no correlation between the principal's leadership style and school performance.

While this study did not prove a correlation between the principal's leadership style and school performance, we should consider the fact that research on transformational and transactional leadership in relation to student achievement or school performance has produced important results. In an answer to the question, "do principals who display transformational leadership have school staff with higher levels of job satisfaction and higher performing schools?", Griffith (2003) found that the principal's transformational leadership showed a strong, positive, and significant relation to the school staff job satisfaction, which in turn showed a moderate, positive and significant relation to the school achievement progress. Thus, schools in which principals were perceived as transformational leaders had school staff that were more satisfied with their jobs and had greater achievement progress. Leithwood and Jantzi (2000) also found substantial effects of transformational leadership on student engagement. It is concluded that transformational leadership might have positive influences beyond increasing student attainment-it may lead to more satisfied and committed teachers who could subsequently influence student learning and school performance, in general.

The study found that female principals are more effective and transformational in their approach than male principals. This finding is in agreement with previous research (Al-Taneiji, 2006; Coleman, 1998; Fennell, 2005; Eagly, Johannesen-Schmidt, and Van Engen, 2003; Kruger 1996). Female principals in the UAE were able to create more transformational atmospheres in their schools and have been able to practice more interpersonal relations and, thus, were seen as more effective than their male counterparts. Moreover, the transformational leadership style is more frequently practiced in kindergartens and cycle 1 schools (grades 1-5) than in intermediate and secondary schools. This is expected in the UAE since principals, teachers, students, and parents take education more seriously during later stages of schooling. Due to the importance ascribed by parents to those later stages and the increasing resistance to change, principals might not have as much freedom for transformational practices as at other levels of schools.

The study found that schools with female principals had better performance than schools with male principals. This might be understandable in light of the fact that female principals are more likely to consider and implement changes to meet performance standards. In fact, the performance of female principals is higher than that of male principals in the UAE (KHDA, 2010). This could be because female principals take a more serious approach than male principals and, thus, might have tried - more than male principals - to raise the level of their schools based on assessment standards. The nature of the education system in the UAE explains why kindergartens and cycle 1 schools performed better than other school levels. In those levels, managing teaching, learning, and students might not be as difficult as in other levels. In addition, there are a greater number of female teachers working at these levels than male teachers.

\section{Conclusions and Recommendations}

Dubai school principals exhibited more transformational than transactional leadership attitudes and behaviors. However, these results were not correlated to the performance levels of schools as assessed by the Dubai Schools Inspections Bureau. This finding supports previous research. The researchers postulate that in order for improved school performance (as seen through student achievement) to take place, school principals should not depend solely on being transformative leaders; they should become instructional leaders and work closely with teachers. In fact, the work of teachers is more directly related to student learning and achievement than the work of principals. Principals spend more time with teachers - providing direction and guidance, assessing and providing needed resources, and observing and evaluating performance - than with students. Thus, principal behaviors more directly affect teachers' satisfaction, commitment to work, and working relations with one another and, accordingly, principal leadership styles have stronger relations to outcomes associated with teachers than with students. Therefore, building on transformational leadership alone will not create the 
Ibrahim, A. S. \& Al-Teneiji, S.

necessary influence to improve student achievement - it should be combined with instructional leadership.

Dubai educational policymakers should exert more efforts to strengthen transformational and instructional leadership in schools if improvement of school performance and student attainment is to be achieved. Quantitative and qualitative research should be conducted on the scale and in the manner that instructional leadership is practiced in Dubai schools. Further, researchers and practitioners should not only be investigating the general or collective impact of leadership styles but also identifying specific leadership attitudes and practices that have stronger impacts on school performance, student achievement, and teacher satisfaction and commitment to work. They should move beyond a general focus on the impact of leadership to examining and increasing the frequency of those practices that make larger positive impacts on teachers and students.

Acknowledgement: This research has been supported by an Internal Grant from the United Arab Emirates University. Grant \#: 01-02-11-201

\section{References:}

Al-Taneiji, S. (2006). Transformational leadership and teacher learning in model schools. Journal of Faculty of Education UAEU, 23, 21-36.

Avolio, B., \& Bass, B. (2004). Multifactor leadership questionnaire (third edition manual and sampler set). MindGarden, Inc.

Avolio, B. \& Bass, B. (1995). Multifactor leadership questionnaire instrument (leader and rater form and scoring guide) (English and Arabic versions). Mind Garden, Inc.

Avolio, B. (1999). Full leadership development: Building the vital forces in organizations. Thousand Oaks, CA: Sage.

Bass, B. (1997). Does the transactional-transformational leadership paradigm transcend organizational and national boundaries? American Psychologist, 52(2), 130-139. <http://dx.doi.org/10.1037/0003-066X.52.2.130>

Bass, B. (1998). Transformational leadership: Industry, military, and educational impact. Mahwah, NJ: Erlbaum Associates.

Bass, B. (1985). Leadership and performance beyond expectations. New York: The Free Press.

Bass, B., \& Avolio, B. (1994) (eds.). Improving organizational effectiveness through transformational leadership. Thousand Oaks, CA: Sage.

Burns, J. (1978). Leadership. New York: Harper \& Row.

Carlson, R. (1996). Reframing and reform: Perspectives on organization, leadership, and school change. White Plains, NY: Longman.

Coleman, M. (1998). The management style of female head-teachers. Educational Management and Administration, 24(2), 163-164.

Cotton, K. (2003). Principals and student achievement. Alexandria, VA: Association for Supervision and Curriculum Development.

Di Vincenzo, R. (2008). School leadership and its relation to school performance. Unpublished Dissertation: University of Phoenix. ProQuest, 3323345.

Dumay, X. (2009). Origins and consequences of school organizational culture for student achievement.

Educational Administration Quarterly, 45(4), 523-555.

$<$ http://dx.doi.org/10.1177/0013161X09335873>

Eagly, A.H., Johannesen-Schmidt, M.C., \& Van Engen, M.L. (2003). Transformational, transactional, and laissez-faire leadership styles: A meta-analysis comparing men and women. Psychological Bulletin, 129, 569-591. <http://dx.doi.org/10.1037/0033-2909.129.4.569> 
Principal leadership style, school performance, and principal effectiveness in Dubai schools

Griffith, J. (2003). Relation of principal transformational leadership to school staff job satisfaction, staff turnover, and school performance. Journal of Educational Administration, 42(3), 333-356.

<http://dx.doi.org/10.1108/09578230410534667>

Hallinger, P. (2003). Leading educational change: Reflections on the practice of instructional and transformational leadership. Cambridge Journal of Education, 33(3), 329-351.

<http://dx.doi.org/10.1080/0305764032000122005>

Hallinger, P., \& Heck, R. (1998). Exploring the principal's contribution to school effectiveness: 1980-1995.

School Effectiveness and School Improvement, 9(2), 157-191.

<http://dx.doi.org/10.1080/0924345980090203>

Harris, A. (2004). Editorial: School leadership and school improvement: A simple and complex relationship, School Leadership and Management, 24(1), 3-5. <http://dx.doi.org/10.1080/1363243042000172778>

Huffman, N. (2003). The relationship of principal leadership style and student achievement in low-socioeconomic schools. Unpublished Doctoral dissertation, Purdue University. ProQuest 3113852.

DSIB (Dubai Schools Inspection Bureau). (2009). Inspection Handbook 2009-2010. Government of Dubai and KDHA. Dubai.

DSIB (2010). Annual Report 2010. Government of Dubai and KDHA. Dubai.

DSIB (2011). Inspection Handbook 2010-2011. Government of Dubai and KDHA. Dubai.

Fennell, H. (2005). Living leadership in an era of change. International Journal of Leadership in Education, 8(2), 145-165. <http://dx.doi.org/10.1080/1360312042000270487>

KHDA (Knowledge and Human Development Authority). (2010). Dubai finds out how much its 15-year-olds know. Retrieved from http://www.ameinfo.com/250976.html

Kouzes, J. (2003). The leadership practices inventory (LPI): Self-instrument (3rd ed.). San Francisco: Jossey-Bass.

Kruger, M. (1996). Gender issues in school headship: quality versus power? European Journal of Education, 31(4), 447-461.

Kruger, M., Witziers, B., \& Sleegers, P. (2007). The impact of school leader variables on school level factors: Validation of a causal model. School Effectiveness and School Improvement, 18(1), 1-20. $<$ http://dx.doi.org/10.1080/09243450600797638>

Kythreotis, A., \& Pashiardis, P. (2006). Exploring leadership role in school effectiveness and the validation of models of principals' effects on students' achievement. Paper presented at the Commonwealth Council for Educational Administration and Management (CCEAM) Conference 2006 "Recreating Linkages between Theory and Praxis in Educational Leadership", Nicosia: Cyprus.

Kythreotis, A., Pashiardis, P., \& Kyriakides, K. (2010). The influence of school leadership styles and culture on students' achievement in Cyprus primary schools. Journal of Educational Administration, 48(2), 218-240. <http://dx.doi.org/10.1108/09578231011027860>

Leithwood, J., \& Jantzi, D. (2000). The effects of transformational leadership on organizational conditions and student engagement. Journal of Educational Administration, 38(2), 112-129. $<$ http://dx.doi.org/10.1108/09578230010320064>

Leithwood, K., Begley, P., \& Cousins, J. (1994). Developing expert leadership for future schools. London: Falmer.

Lewin, K., Lippit, R., \& White, R. (1939). Patterns of aggressive behavior in experimentally created social climates. Journal of Social Psychology, 10, 271-301. <http://dx.doi.org/10.1080/00224545.1939.9713366>

Likert, R. (1967). The human organization: Its management and value. New York: McGraw-Hill.

Marks, H., \& Printy, S. (2003). Principal leadership and school performance: An integration of transformational and instructional leadership. Educational Administration Quarterly, 39(3), 370-397. $<$ http://dx.doi.org/10.1177/0013161X03253412>

Silins, H., \& Mulford, B. (2002). Leadership and school results. Second International Handbook of Educational Leadership and Administration (pp. 561-612). Dordrecht: Kluwer. <http://dx.doi.org/10.1007/978-94-010-0375-9_21> 
Ibrahim, A. S. \& Al-Teneiji, S.

Storey, A. (2004). The problem of distributed leadership in schools. School Leadership and Management, 24(3), 249-265. <http://dx.doi.org/10.1080/1363243042000266918>

Ubben, G., \& Hughes, L. (1992). The principal: Creative leadership for effective schools. Meedham Heights, MA: Allyn and Bacon.

Waters. T., Marzano, R., \& McNulty, B. (2004). Leadership that sparks learning. Educational Leadership, 61(1), 48-52.

Witziers, B., Bosker, R., \& Kruger, M. (2003). Educational leadership and student achievement: The elusive search for an association. Educational Administration Quarterly, 39(3), 398-425.

$<$ http://dx.doi.org/10.1177/0013161X03253411> 